\title{
Udział Polskiego Autokefalicznego Kościoła Prawosławnego w przygotowaniach Soboru Wszechprawosławnego
}

W przygotowaniach do Soboru Wszechprawosławnego z założenia powinien uczestniczyć cały Kościół prawosławny. Wyrażeniem tej pełni Kościoła jest udział wszystkich lokalnych Kościołów autokefalicznych w tym procesie. Fakt, że Polski Autokefaliczny Kościół Prawosławny (PAKP) od 1925 roku cieszy się statutem Kościoła autokefalicznego, sprawia, że Kościół ten jest pełnoprawnym członkiem całego procesu przygotowawczego. Już w okresie międzywojennym, kiedy rodziła się idea zwołania wszechprawosławnego soboru, delegaci PAKP brali udział w spotkaniach przygotowawczych ${ }^{1}$.

${ }^{1}$ Mam na uwadze przede wszystkim spotkanie na Świętej Górze Athos w monasterze Watopedi, które odbyło się w dniach 8-24 czerwca 1930 roku. W spotkaniu tym brali udział dwaj biskupi z Polski: metropolita warszawski i całej Polski Dionizy (Waledyński) i arcybiskup grodzieński Aleksy (Gromadzki). Kolejną inicjatywą był Kongres teologów prawosławnych w Atenach w 1936 roku, w którym uczestniczyło dwóch teologów z Polski: archimandryta Hilarion (Bazdekas) i prof. Nikołaj Arsieniew. Natomiast prof. Michał Zyzykin nie dojechał na spotkanie, ale został odczytany jego referat. Zob. NSO, s. 148 i 150. 
W okresie powojennym znaczącą rolę w procesie przygotowawczym odegrały konferencje wszechprawosławne. Na I Konferencji Wszechprawosławnej, która odbyła się w dniach 29 września - 1 października 1961 roku na wyspie Rodos, została podjęta decyzja o rozpoczęciu przygotowań Soboru Wszechprawosławnego. Ustalono też listę tematów dla przyszłego soboru i procedurę jego przygotowań. W Konferencji tej uczestniczyła delegacja PAKP w następującym składzie: metropolita warszawski i całej Polski Tymoteusz (Szretter), arcybiskup białostocki i gdański Stefan (Rudyk), ks. Konstanty Gromadzki i ks. Aleksy Znosko². Dalszych ustaleń w sprawie tematyki, jaką będzie zajmował się przyszły sobór, oraz sposobu jego przygotowań dokonała IV Konferencja Wszechprawosławna, która odbyła się w nowo otwartym Centrum Patriarchatu Ekumenicznego w Chambésy koło Genewy. W czasie Konferencji powołano stały Sekretariat do spraw Przygotowania Świętego i Wielkiego Soboru Kościoła prawosławnego. PAKP na tym spotkaniu reprezentowali: biskup białostocki i gdański Nikanor (Niesłuchowski) i ks. Jerzy Klinger ${ }^{3}$.

Na spotkaniu w Chambésy w 1968 roku postanowiono także zwoływać przygotowawcze Wszechprawosławne Konferencje Przedsoborowe. Pierwsza taka Konferencja odbyła się w Chambésy w dniach 21-28 listopada 1976 roku. Dokonała ona między innymi rewizji listy tematów, którymi powinien zająć się przyszły sobór, i określiła metodę dalszych prac przygotowawczych zmierzających do zwołania soboru4. W skład delegacji PAKP na tym spotkaniu wchodzili: igumen Szymon (Romańczuk), który był przewodniczącym delegacji, ks. Mikołaj Lenczewski i ks. Eugeniusz Pańko. Delegacja Kościoła polskiego stanowiła swego rodzaju wyjątek

${ }^{2}$ Zob. Bсеправославное совещзание на о. Poдосе, ŻMP 1961, nr 11, s. 3-4. W dwóch kolejnych konferencjach na Rodos nie brali udziału przedstawiciele PAKP. Nie były one jednak poświęcone sprawie zwołania soboru ogólnoprawosławnego.

${ }^{3}$ Zob. J. Klinger, Konferencja Przedstawicieli Kościołów Prawosławnych w Chambésy koło Genewy, „Cerkiewny Wiestnik” 15 (1968) nr 8, s. 12.

${ }^{4}$ Zob. Synodica III, s. 11. 
pośród innych delegacji. Na jej czele nie stał biskup, jak w przypadku pozostałych delegacji lokalnych Kościołów prawosławnych, którym przewodniczyli hierarchowie w randze metropolity ${ }^{5}$. W czasie świętej liturgii sprawowanej pod przewodnictwem metropolity Chalcedonu Chryzostoma, w której uczestniczyli przewodniczący wszystkich delegacji, dla ks. igumena Szymona, przewodniczącego polskiej delegacji, zostało przydzielone pierwsze miejsce wśród prezbitrów uczestniczących w świętej liturgii ${ }^{6}$.

W toku obrad Konferencji Przedsoborowej (1976) zostały powołane trzy komisje. Zadaniem pierwszej komisji była rewizja listy tematów przeznaczonych na ogólnoprawosławny sobór oraz analiza procedury soborowych przygotowań. Do tej komisji z ramienia PAKP wszedł igumen Szymon (Romańczuk). Do komisji zajmującej się relacjami i dialogiem z innymi Kościołami chrześcijańskimi został włączony ks. Mikołaj Lenczewski. Natomiast ks. Eugeniusz Pańko wszedł do komisji, która zajmowała się kwestią ustalenia wspólnej daty świętowania Paschy ${ }^{7}$. Analizując sprawozdania tych trzech komisji zaprezentowane na spotkaniu plenarnym, można stwierdzić, że ich prace okazały się bardzo owocne. Dziesięć tematów wskazanych przez pierwszą komisję znalazło się w przyjętym przez Konferencję katalogu tematów dla przyszłego soboruํ. Druga komisja natomiast

${ }^{5}$ Lista uczestników spotkania zob. Synodica III, s. 8-9. Regulamin przygotowań do Soboru Wszechprawosławnego zakłada, że na czele delegacji autokefalicznego Kościoła prawosławnego powinien stać biskup. Pozostali członkowie mogą być osobami duchownymi lub też świeckimi. Zdarzały się jednak odstępstwa od tej zasady. Nigdy jednak nie kwestionowano ważności wypracowanych w toku takich spotkań dokumentów, podpisanych przez osobę niebędącą biskupem.

${ }^{6}$ Zob. Synodica III, s. 25.

${ }^{7}$ Lista członków poszczególnych Komisji zob. Synodica III, s. 84-86.

${ }^{8}$ Są to następujące tematy: 1) Diaspora prawosławna; 2) Autokefalia i sposób jej ogłaszania; 3) Autonomia i sposób jej ogłaszania; 4) Porządek dyptychów; 5) Zagadnienie wspólnego kalendarza; 6) Przeszkody w zawieraniu związków małżeńskich; 7) Przystosowanie przepisów kościelnych dotyczących postu zgodnie ze współczesnymi wymogami; 8) Relacje Kościołów prawosławnych z całym światem chrześcijańskim; 9) Prawosławie wobec ruchu ekumenicznego; 10) Wkład lokalnych 
dokonała gruntownej analizy dialogów Kościoła prawosławnego z innymi Kościołami chrześcijańskimi, jak też oceny relacji prawosławia ze Światową Radą Kościołów. Owoce jej prac zostały zawarte w odpowiednim projekcie dokumentu dla przyszłego soboru. Trzecia komisja opracowała zagadnienie możliwości wspólnego świętowania Wielkanocy przez wszystkich chrześcijan. W swoim opracowaniu nie bez racji wskazała na prawdopodobieństwo wystąpienia problemów w wymiarze pastoralnym. Ostatecznie stanowisko komisji w sprawie wspólnego świętowania Wielkanocy znalazło swoje odbicie w dokumencie Zagadnienie nowego kalendarza, który był przyjęty przez następną Konferencję .

Druga Konferencja Przedsoborowa odbyła się w dniach 3-12 września 1982 roku. W skład delegacji PAKP uczestniczącej w tej Konferencji wchodzili: biskup białostocki i gdański Sawa (Hrycuniak) jako przewodniczący delegacji, ks. Aleksy Semeniuk i dr Jan Anchimiuk. Polska delegacja przyjechała z opóźnieniem i biskup Sawa był nie obecny na spotkaniu przewodniczących delegacji, które zwykle odbywa się jeszcze przed rozpoczęciem plenarnych obrad ${ }^{10}$. Na Konferencji zostały rozpatrzone trzy zagadnienia: postu, przeszkód małżeńskich i kalendarza. Odnośnie do tych tematów sobór biskupów PAKP przysłał swoje propozycje i uwagi, które były ujęte w projektach dokumentów przygotowanych kilka miesięcy wcześniej przez Komisję Przygotowawczą ${ }^{11}$. W toku obrad Konferencji powołano trzy komisje robocze. W skład pierwszej zajmującej się Przystosowaniem przepisów

Kościołów prawosławnych w realizację chrześcijańskich ideałów pokoju, wolności, braterstwa i miłości miedzy narodami oraz zniesienie dyskryminacji rasowej. Sformułowania tych tematów potem były nieco modyfikowane i ostatecznie przybrały nieco inne brzmienie.

${ }^{9}$ Zob. Synodica III, s. 108-109.

${ }_{10}$ Zob. Synodica VIII, s. 9.

${ }^{11}$ Propozycje soboru biskupów PAKP w dużej mierze dotyczyły złagodzenia wymogów postu wobec wiernych. Proponowano m.in., aby w czasie Wielkiego Postu dopuszczać spożywanie ryb, w czasie postu bożonarodzeniowego dopuszczać spożywanie produktów mlecznych, jak też skrócenie tego postu. Zob. tamże s. 164 . 
kościelnych dotyczacych postu, został włączony ks. Aleksy Semeniuk, do komisji zajmującej się Przeszkodami małżeńskimi - biskup Sawa (Hrycuniak), natomiast do komisji zajmującej się Zagadnieniem kalendarza - dr Jan Anchimiuk ${ }^{12}$. W toczącej się dyskusji, zwłaszcza na temat postu i kalendarza, rysowała się wyraźna linia podziału pomiędzy zwolennikami zmian w Kościele i tymi, którzy nie tyle odrzucali zmiany, lecz obawiali się schizmy wewnątrz Kościoła. Z tego względu uwagi wielu Kościołów, które były przesłane jako propozycje do opracowywanych dokumentów, należało w pewien sposób skorygować lub zmienić. Dlatego też delegacja PAKP wycofała propozycje, które były przysłane jako oficjalne stanowisko soboru biskupów PAKP ${ }^{13}$. Rezultatem obrad II Konferencji Przedsoborowej było przyjęcie dwóch dokumentów: 1) Przeszkody małżeńskie i 2) Zagadnienie kalendarza. Dokument dotyczący postu został przekazany do ponownego rozpatrzenia na następnej Konferencji Przedsoborowej.

W III Konferencji Przedsoborowej, która odbyła się w dniach 28 październia - 6 listopada 1986 roku w Chambésy, uczestniczyła delegacja PAKP w składzie: biskup wrocławski i szczeciński Jeremiasz (Anchimiuk) - przewodniczący delegacji ${ }^{14}$, ks. Jerzy

${ }^{12}$ Zob. Synodica VIII, s. 64.

${ }^{13}$ Zob. Synodica VIII, s. 170. Atmosfera tego spotkania została zrelacjonowana przez członka polskiej delegacji, Jana Anchimiuka w następujący sposób: „W Kościele prawosławnym nie da się przeprowadzić podziału na dogmatykę, pojmowaną jako «teoria» i praktyka. Teoria pojmowana jest jako wyraz życia Kościoła. Oznacza to, że każde posunięcie czy zarządzenie w sferze «praktyki» jest równoznaczne z zajęciem tego lub innego stanowiska w sferze doktrynalnej i odwrotnie [...]. Wprowadzenie nowego stylu doprowadziłoby w niektórych Kościołach do powstania rozłamów [...]. Albowiem jest to sprawa nie tylko dokładnych wyliczeń astronomicznych, lecz także realności kosmicznego znaczenia Zmartwychwstania". J. Anchimiuk, Przygotowania do Soboru Wszechprawosławnego, WPAKP 1983, nr 1-2, s. 80. Zob. J. Tofiluk, O przygotowaniach do Soboru Wszechprawostawnego, „Elpis” 1 (1999) nr 1, s. 79-80.

${ }^{14}$ Dr Jan Anchimik, który uczestniczył w II Konferencji Przedsoborowej w 1982 roku, w lutym 1983 roku został wyświęcony najpierw na diakona, potem na kapłana, następnie został postrzyżony do stanu zakonnego, przyjmując imię Jeremiasza, i w marcu 1983 roku został podniesiony do godności biskupiej. W kolejnych spotkaniach 
Tofiluk i mgr Mikołaj Kozłowski ${ }^{15}$. Tematy znajdujące się w porządku obrad Konferencji były rozpatrywane w czterech komisjach. Biskup Jeremiasz został powołany przez Komisję przygotowawczą na przewodniczącego komisji, której zadaniem było wstępne przygotowanie projektu dokumentu Prawosławie i ruch ekumeniczny. Do komisji zajmującej się dokumentem Znaczenie postu i jego zachowanie dzisiaj został włączony ks. Jerzy Tofiluk, natomiast do komisji omawiającej Relacje Kościołów prawosławnych z pozostałym światem chrześcijańskim Mikołaj Kozłowski. W komisji pracującej nad dokumentem Wkład Kościoła prawosławnego w realizacje pokoju, sprawiedliwości, wolności, braterstwa i miłości między narodami oraz zniesienie dyskryminacji rasowej i innych nie było przedstawiciela PAKP ${ }^{16}$.

Rezultatem III Konferencji Przedsoborowej było przyjęcie wszystkich czterech dokumentów jako projektów na Sobór Wszechprawosławny. W ten sposób, biorąc pod uwagę rezultaty II i III Konferencji Przedsoborowej, sześć tematów spośród dziesięciu, które były określone przez I Konferencję Przedsoborową okazało się gotowymi propozycjami na sobór. Konferencja postanowiła o podjęciu prac nad pozostałymi czterema tematami: 1) Diaspora prawosławna; 2) Autokefalia i sposób jej ogłaszania; 3) Autonomia i sposób jej ogłaszania; 4) Dyptychy.

Prace nad tymi tematami podjęła Komisja Przygotowawcza na posiedzeniu w dniach 10-17 listopada 1990 roku. W posiedzeniu Komisji uczestniczył biskup wrocławski Jeremiasz oraz ks. Jerzy Tofiluk jako doradca. W odpowiedzi na prośbę Sekretariatu Kościoły lokalne przysłały swoje stanowiska w odniesieniu do czterech wspomnianych zagadnień ${ }^{17}$.

przygotowawczych będzie uczestniczył najpierw jako biskup, potem zaś jako arcybiskup Jeremiasz.

${ }^{15}$ Pełna lista uczestników i stenogram obrad III Konferencji zob. Synodica X.

${ }^{16}$ Synod biskupów PAKP nie przysłał swoich uwag lub propozycji odnośnie do omawianych tematów.

${ }^{17}$ Wszystkie opracowania zostały przetłumaczone i wydrukowane w trzech językach. Dokonana została też przez sekretarza do spraw przygotowania soboru, 
Biskupi PAKP swoje stanowisko wobec czterech zagadnień przysłali w bardzo krótkiej formie, daleko odbiegającej od szczegółowych opracowań innych Kościołów. Stanowisko polskiej Cerkwi wobec problemu diaspory zawierało się w jednym zdaniu: „Każdy Kościół Matka posiada prawo i obowiązek troszczyć się o swoją diasporę"18. Takie stwierdzenie, stawiało polski Kościół w szeregu wraz z tymi Kościołami, które podkreślały jurysdykcyjną więź wspólnot będących w diasporze z lokalnym Kościołem Matką. Propozycja dotycząca stworzenia pewnej platformy współpracy prawosławnych biskupów będących w diasporze na określonym terytorium była wyraźnie zaznaczona w opracowaniu przysłanym przez Patriarchat Ekumeniczny ${ }^{19}$. Wydaje się jednak, że waga takiego rozwiązania została w znaczący sposób zaakcentowana w czasie dyskusji przez biskupa Jeremiasza (Anchimiuka). Przedstawiciel PAKP powołał się na już istniejące formy takiej współpracy we Francji i USA, proponując powołanie „czegoś w rodzaju Konferencji Biskupów”20. Komisja przygotowawcza nie zdołała jednak wypracować projektu dokumentu o Diasporze prawosławnej ${ }^{21}$.

Kolejne posiedzenie Komisji Przygotowawczej odbyło się w dniach 7-13 listopada 1993 roku. Przedstawicielem PAKP na tym

metropolitę Damaskinosa, analiza punktów wspólnych i punktów rozbieżnych w postrzeganiu poszczególnych tematów: Доклад о совпаденияхи расхождениях по четырем темам повестки дня IV Всеправославного Предсоборного Совещания, wyd. Secrétariat pour la préparation du Saint et Grande Concile de l'Eglise Orthodoxe, Chambésy-Genève 1987 (maszynopis cz. I i II).

${ }^{18}$ Мнение епископов Польской Автокефальной Православной Церкви по вопросам: автокефалии, автономии, диаспрры и диптиха. Татże s. 1-2.

${ }^{19}$ Доклад о совпадениях и расхождениях..., dz. суt., s. 7.

${ }^{20}$ Propozycja ta została wyrażona w drugim dniu obrad Komisji. Zob. stenogram: Межправославная Подготовительная Комиссия Святого и Великого Собора Православной Церкви, 10-17 ноября 1990 г. (maszynopis) Шамбези-Женева 1991, s. 76. W ostatecznej wersji ta platforma współpracy biskupów w diasporze została określona „Zgromadzeniem Biskupów”. Takie sfomułowanie miało na celu odróżnienie tego prawosławnego eklezjalnego ciała od już istniejących rzymskokatolickich „Konferencji Episkopalnych”.

${ }^{21}$ Zob. Komunikat końcowy, tłum. polskie: NSO, s. 458-459. 
spotkaniu była tylko jedna osoba - biskup wrocławski i szczeciński Jeremiasz (Anchimiuk). Komisja dokończyła pracę nad dokumentem na temat diaspory. Zajęła się również kolejnym tematem z katalogu czterech zagadnień, mianowicie kwestią nadawania autokefalii. Temat ten okazał się nie mniej trudnym od sprawy diaspory. Biskupi PAKP w przesłanym do Sekretariatu stanowisku autokefalii poświęcili więcej miejsca niż zagadnieniu diaspory. $\mathrm{W}$ ośmiu nadesłanych opracowaniach, jak zauważył sekretarz do spraw przygotowań soboru, rysowały się dwie główne drogi - procedury nadawania autokefalii: 1) akcentująca rolę soboru, bądź to powszechnego, jeśli chodzi o Kościół starożytny, bądź też ogólnoprawosławnego, i przewodnią rolę Patriarchatu Ekumenicznego w tym dziele; 2) podkreślająca zasadniczą rolę Kościoła Matki, z którego wyłania się nowy Kościół autokefaliczny 22 .

Stanowisko biskupów PAKP w sprawie autokefalii brzmiało następująco: ,a) Według naszego uznania autokefalię może nadać Kościół Matka, który sam posiada kanoniczną autokefalię i znajduje się w kanonicznej jedności z całą pełnią prawosławia, b) bez błogosławieństwa Kościoła Matki nadanie autokefalii jest niekanoniczne”. Dalej biskupi polskiego Kościoła odnieśli się do rozwiązywania kwestii spornych w nadawaniu autokefalii, uznając autokefalię Kościoła Czech i Słowacji, jak też Kościoła amerykańskiego ${ }^{23}$. PAKP przychylał się w swej opinii na temat autokefalii do tej drugiej procedury nadawania autokefalii i był bliski stanowisku zawartemu w raporcie Patriarchatu Moskiewskiego, Rumuńskiego i Bułgarskiego ${ }^{24}$.

${ }^{22}$ Zob. Raport Metropolity Szwajcarii Damaskinosa, wygłoszony w czasie spotkania Komisji: Межправославная Подготовительная Комиссия Святого и Великого Собора, 7-13 ноября 1993 г. (maszynopis) Шамбези-Женева 1994, s. 167.

${ }_{23}$ Мнение епископов Польской Автокефальной Православной Церкви по вопросам: автокефалии, автономии, диаспрры и диптиха. s. 1-2, [w:] Доклад о совпадениях и расхождениях (...). Tłum. polskie zob. J. Tofiluk, o przygotowaniach do Soboru Wszechprawosławnego, „Elpis” 1 (1999) nr 1 (14), s. 80.

${ }^{24}$ Межправославная Подготовительная Комиссия Святого и Великого Собора, 7-13 ноября 1993 2, s. 167 (maszynopis) Шамбези-Женева 1994. 
Komisja 1993 roku dokonała wstępnego opracowania tematu Diaspory prawosławnej. W oddzielnym dokumencie sformułowała też główne punkty dotyczące Autokefalii i sposobujej ogłaszania. Poprosiła ponadto Sekretariat o sporządzenie projektu regulaminu funkcjonowania zgromadzeń biskupów. Pomocnym w tym zadaniu miało być zorganizowanie konferencji prawosławnych teologów i kanonistów, która odbyła się w dniach 10-13 kwietnia 1995 roku w Chambésy. Na spotkaniu tym nie było przedstawicieli PAKP. Rezultatem obrad konferencji było opracowanie projektu Regulaminu funkcjonowania Zgromadzeń Biskupów. Po niewielkich poprawkach dokument ten został przyjęty przez IV Konferencję Przedsoborową (2009).

Podczas kolejnego posiedzenia w dniach od 28 lutego do 6 marca 1999 roku Komisja kontynuowała pracę nad tekstem o autokefalii i podjęła temat dyptychów. PAKP reprezentował na tym spotkaniu arcybiskup wrocławski i szczeciński Jeremiasz (Anchimiuk). Uczestnicy spotkania nie wypracowali wspólnego stanowiska w rozpatrywanych kwestiach ${ }^{25}$.

Dalsze prace związane z przygotowaniem Soboru Wszechprawosławnego znacząco zwolniły tempo. Przyczyniły się do tego m.in. konflikt między Patriarchatem Moskiewskim i Patriarchatem Konstantynopolitańskim, dotyczący nadania przez ten ostatni statusu Kościoła autonomicznego prawosławnej Metropolii w Estonii, jak również choroba sekretarza Sekretariatu do spraw Przygotowania Soboru, metropolity Szwajcarii Damaskinosa (Papandreu) ${ }^{26}$. Decyzja o wznowieniu soborowych przygotowań zapadła podczas zgromadzenia zwierzchników autokefalicznych Kościołów prawosławnych, które odbyło się w dniach 10-12 października 2008 roku $^{27}$. W dniach 6-13 czerwca 2009 roku w Chambésy odbyła się IV Konferencja

${ }^{25}$ Tekst komunikatu: NSO, s. 466.

${ }^{26}$ Metropolita Damaskinos zmarł w 2011 roku i został pochowany obok cerkwi na terenie Centrum Patriarchatu Ekumenicznego w Chambésy, którego był budowniczym i dyrektorem od początku jego funkcjonowania.

${ }^{27}$ Zob. A. Kuźma, Spotkanie Zwierzchników i Przedstawicieli Lokalnych Kościołów prawosławnych w Konstantynopolu, WPAKP 2008, nr 12 (229), s. 4-5. 
Przedsoborowa. Sobór biskupów PAKP na tę Konferencję wydelegował arcybiskupa Jeremiasza (Anchimiuka) i ks. Andrzeja Kuźmę. Uczestnictwo arcybiskupa Jeremiasza (Anchimiuka) w spotkaniu, ze względów zdrowotnych, nie było jednak możliwe. Przewodniczącym delegacji PAKP na IV Konferencję Przedsoborową był biskup siemiatycki Jerzy (Pańkowski), prawosławny ordynariusz Wojska Polskiego.

IV Konferencja została poświęcona dyskusji i pracy nad tematem Diaspory prawosławnej. Debata toczyła się w dużej mierze nad kwestią przewodnictwa w Zgromadzeniach Biskupów i nad sposobem podejmowania przez nie decyzji. W poszukiwaniu kompromisu delegat PAKP biskup siemiatycki Jerzy proponował, aby przewodnictwo w Zgromadzeniu było oparte na zasadzie rotacji. Taka forma odpowiadała m.in. przedstawicielom Patriarchatu Moskiewskiego. Jednak nie uzyskała ona szerszego wsparcia. W rezultacie dyskusji na temat tych dwóch punktów uczestnicy Konferencji zgodzili się, aby przewodniczącym Zgromadzenia Biskupów pozostawał najstarszy rangą hierarcha Patriarchatu Konstantynopola, ale uznali jednocześnie, że decyzje podejmowane przez ten organ powinny być podejmowane na zasadzie konsensusu, a nie większością głosów. Takie założenia znalazły się też w projekcie dokumentu na Sobór Wszechprawosławny Diaspora prawosławna. Na IV Konferencji został też przyjęty projekt Regulaminu funkcjonowania Zgromadzeń Biskupów w diasporze prawosławnej z naniesionymi przez Konferencję poprawkami ${ }^{28}$.

W dniach 9-17 grudnia 2009 roku została zwołana Komisja Przygotowawcza, której zadaniem było zajęcie się pozostałymi tematami, czyli sposobem nadawania autokefalii, nadawania autonomii i zagadnieniem dyptychów. Ze strony PAKP w spotkaniu brali udział biskup siemiatycki Jerzy (Pańkowski) i ks. Andrzej Kuźma. Komisja wiele czasu poświęciła zagadnieniu nadawania autokefalii, jednak nie zdołano wypracować wspólnego dokumentu. Stanowisko

${ }^{28}$ Zob. A. Kuźma, IV Konferencja Przedsoborowa, WPAKP 2009, nr 7-8 (236-237), s. $4-5$. 
biskupów PAKP w tej kwestii zostało wymienione w raporcie sekretarza do spraw przygotowania soboru w roku 1987. W zasadzie łączy ono nadawanie autonomii i autokefalii w jeden proces, w którym bierze udział Kościół Matka, jak również Patriarchat Ekumeniczny. Procedura zatwierdzenia zaś nowej kościelnej struktury powinna przebiegać na poziomie ogólnoprawosławnym. Owocem prac Komisji był projekt dokumentu o nadawaniu autonomii. Nie udało się jednak dokończyć prac nad zagadnieniem autokefalii. Zabrakło też czasu na zajęcie się tematem dyptychów ${ }^{29}$.

Prace nad zagadnieniami autokefalii i dyptychów kontynuowała Komisja Przygotowawcza na kolejnym posiedzeniu w dniach 21-27 lutego 2011 roku. Na spotkanie to z PAKP przybył arcybiskup Jeremiasz (Anchimiuk) oraz ks. Andrzej Kuźma (doradca). Kontrowersyjną kwestią przy opracowaniu zagadnienia autokefalii była forma podpisywania tomosu o nadaniu autokefalii. Delegacja Patriarchatu Konstantynopola obstawała przy tym, aby podpis patriarchy Konstantynopola w ten czy w inny sposób został wydzielony spośród innych podpisów zwierzchników autokefalicznych Kościołów lokalnych. Delegaci innych Kościołów lokalnych w odmienny sposób jednak interpretowali tę kwestię. Przedstawiciel PAKP wyrażał opinię, że podpis patriarchy Konstantynopola nie powinien być opatrzony dodatkowymi opisami czy też w szczególny sposób wyróżniony. Powinien znajdować się na pierwszym miejscu, poprzedzając podpisy innych zwierzchników ${ }^{30}$. W ten sposób kolejna próba opracowania dokumentu o nadawaniu autokefalii okazała się nieudana.

Niemożliwe okazało się także wypracowanie wspólnego stanowiska w sprawie dyptychów. Główny problem pojawia się przy

\footnotetext{
${ }^{29}$ Межправославная Подготовительная Комиссия 9-17 декабря 2009 г. Шамбези Комюнике (maszynopis).

${ }^{30}$ Zob. wypowiedzi arcybiskupa Jeremiasza, Commision interorthodoxe préparatoire au saint et Grand Concile, Chambésy, 21-27 fevrier 2011, Actes- Documents , Centre Orthodoxe du Patriarchat Oecuménique, Chambésy-Genève (maszynopis), s. 220, 226.
} 
jednoznacznym określeniu miejsca Patriarchatu Gruzińskiego. Kościół ten w dyptychach używanych przez Patriarchat Ekumeniczny i część Kościołów niegreckojęzycznych znajduje się na dziewiątym miejscu. Pragnieniem Patriarchatu Gruzińskiego jest, aby został on przyznany na miejscu szóstym, bezpośrednio po Patriarchacie Moskiewskim. Należy dodać, że w dyptychu stosowanym przez PAKP takie właśnie miejsce Kościoła gruzińskiego jest mu przydawane. Pozycja polskiego Kościoła prawosławnego, potwierdzająca takie właśnie stanowisko, wyrażana była zarówno w propozycjach z 1987 roku, jak też w trakcie obecnych spotkańn ${ }^{31}$. Problemem, który również nie został rozwiązany do tej pory, pozostaje miejsce w dyptychu Polskiego Autokefalicznego Kościoła Prawosławnego. W dyptychu Patriarchatu Konstantynopola, jak również tym stosowanym przez PAKP, Kościół polski umiejscowiony jest na pozycji dwunastej, przed Kościołem albańskim. W dyptychu Patriarchatu Moskiewskiego i jeszcze w dyptychach kilku lokalnych Kościołów, PAKP zajmuje miejsce trzynaste, po Kościele albańskim. Sobór biskupów PAKP nigdy nie nalegał, by przydana mu została koniecznie pozycja dwunasta, godził się na pozycję trzynastą, „aby zachowany został pokój w Kościele powszechnym”32. Jednak Kościół albański kategorycznie odmawia zajmowania miejsca dwunastego, twierdząc, że w porządku kanonicznym przynależy mu miejsce po Kościele polskim ${ }^{33}$. W takiej sytuacji, jak się okazuje, nie jest to problem Kościołów albańskiego i polskiego, ale raczej Patriarchatu Moskiewskiego, który uważa autokefalię albańską za starszą. W związku z tym, że większość lokalnych autokefalicznych Kościołów przyznaje PAKP dwunaste miejsce, delegacja Kościoła polskiego zwróciła się do Patriarchatu Moskiewskiego o udzielenie w swoim dyptychu również tego miejsca ${ }^{34}$. Sprawa zarówno

${ }^{31}$ Zob. Доклад о совпадениях и расхождениях..., dz. cyt., cz. I і II.

${ }^{32}$ Zob. tamże.

${ }^{33}$ Commision interorthodoxe préparatoire au saint et Grand Concile, Chambésy, 21-27fevrier 2011, Actes- Documents (maszynopis), dz. cyt., s. 248, 252nn.

${ }^{34}$ Zob. tamże s. 253. 
Patriarchatu Gruzińskiego, jak też Kościoła polskiego i albańskiego, pozostaje nadal otwarta i potrzebuje dalszych uzgodnień. Należy nadmienić, że na tym spotkaniu zostało zgłoszone roszczenie Kościoła cypryjskiego o przyznanie mu „bardziej godnego miejsca w dyptychu". Taki stan rzeczy jeszcze bardziej skomplikował proces stworzenia projektu dokumentu o ustanowieniu jednego dyptychu. Bez wątpienia należy jednak stwierdzić, że pewne postępy zarówno w temacie o nadawaniu autokefalii, jak też w kwestii dyptychów, zostały poczynione. Punkty wspólne i rozbieżności zostały nakreślone w trzech podpisanych dokumentach zamykających to spotkanie ${ }^{35}$.

Po spotkaniu w 2011 roku nastąpiła dość długa przerwa w procesie przygotowawczym. Kolejnym ważnym krokiem było spotkanie zwierzchników autokefalicznych Kościołów prawosławnych w marcu 2014 roku. Delegacja PAKP na to spotkanie przybyła w składzie: metropolita warszawski i całej Polski Sawa - przewodniczący, biskup siemiatycki Jerzy i ks. archimandryta Andrzej (Borkowski). Na spotkaniu określono datę przyszłego soboru na okres Pięćdziesiątnicy 2016 roku. Postanowiono także powołać specjalną Komisję, której zadaniem będzie gruntowne przepracowanie trzech tekstów już przyjętych przez Konferencje Przedsoborowe, jak też nieznaczne przeredagowanie trzech innych tematów również przyjętych już wcześniej przez Konferencje ${ }^{36}$. Sobór biskupów PAKP do Komisji oddelegował biskupa siemiatyckiego Jerzego jako przewodniczącego i ks. Andrzeja Kuźmę w roli doradcy. Komisja rozpoczęła pracę jesienią 2014 roku i w sumie odbyła trzy posiedzenia ${ }^{37}$.

Uaktualnione dokumenty były przedkładane na bieżąco do akceptacji przez sobory lub synody poszczególnych autokefalicznych Kościołów prawosławnych. Sobór biskupów PAKP zajął się tym

${ }^{35}$ Trzy podpisane dokumenty to: 1) Signature du Tome d'Autocéphalie, 2) Les Diptyques orthodoxe, 3) Communiqué, opublikowane: tamże s. 275-286.

${ }^{36}$ Zob. Decyzja Zwierzchników Cerkwi Prawosławnych, WPAKP 2014, nr 4 (293), s. 3.

${ }^{37}$ Spotkania Komisji odbyły się w Centrum Patriarchatu Ekumenicznego w Chambésy w następujących terminach: pierwsze: 29 września - 4 października 2014; drugie: 15-21 lutego 2015; trzecie: 29 marca - 3 kwietnia 2015. 
zagadnieniem na swoim posiedzeniu w dniu 18 listopada $2014 \mathrm{roku}^{38}$. Dla wniesienia poprawek do dokumentu Relacje Kościoła prawosławnego z pozostałym światem chrześcijańskim została powołana Komisja pod przewodnictwem arcybiskupa wrocławskiego i szczecińskiego Jeremiasza (Anchimiuka), w której skład weszli: biskup supraski Grzegorz (Charkiewicz) i biskup siemiatycki Jerzy (Pańkowski), ordynariusz Wojska Polskiego. Komisja spotkała się w grudniu 2014 roku w Supraślu i zaproponowała kilka zmian dotyczących wspólnej modlitwy z innowiercami i przeszkód, jakie z tego się wyłaniają w kontekście prawa kanonicznego. Propozycje zostały przesłane do Sekretariatu do spraw Przygotowania Soboru ${ }^{39}$.

Opracowane dokumenty, poprawione przez lokalne sobory lub synody, stały się przedmiotem dyskusji na V Wszechprawosławnej Konferencji Przedsoborowej, która odbyła się w dniach 10-17 października 2015 roku w Centrum Patriarchatu Ekumenicznego w Chambésy. Przedstawicielami PAKP na tym spotkaniu byli: biskup siemiatycki Jerzy (Pańkowski) - przewodniczący delegacji, i ks. Andrzej Kuźma. Konferencja poprawiła i przyjęła jednogłośnie jako projekty dokumentów dla Soboru Wszechprawosławnego następujące teksty: 1) Autonomia i sposób jej ogłaszania; 2) Relacje Kościoła prawosławnego z pozostałym światem chrześcijańskim; 3) Znaczenie postu i jego zachowanie dzisiaj. Dokument Wkład Kościoła prawosławnego $w$ realizację pokoju, sprawiedliwości, wolności, braterstwa i miłości między narodami oraz zniesienie dyskryminacji rasowej i innych, w swojej ostatecznej formie uzyskał nieco zmieniony tytuł: Misja Kościoła prawosławnego we wspótczesnym świecie. (Wkład Kościoła prawosławnego $w$ realizację pokoju sprawiedliwości, wolności braterstwa i miłości między narodami i zniesienie dyskryminacji rasowej $i$ innych), jednak

\footnotetext{
${ }^{38}$ Zob. Z prac Świetego Soboru Biskupów Polskiego Autokefalicznego Kościoła Prawosławnego, WPAKP 2014, nr 12 (301), s. 4-5.

${ }^{39}$ V Konferencja Przedsoborowa nie przyjęła jednak zaproponowanych przez PAKP zmian.
} 
nie uzyskał on powszechnej aprobaty - nie został podpisany przez Patriarchaty Moskiewski i Gruziński ${ }^{40}$.

Ostatnim etapem w przygotowaniach do soboru było zgromadzenie zwierzchników autokefalicznych Kościołów prawosławnych, które odbyło się w Chambésy w dniach 21-28 stycznia 2016 roku. Na spotkanie to nie mógł przybyć zwierzchnik PAKP metropolita Sawa ze względów zdrowotnych. Przedstawicielem PAKP na tym spotkaniu był biskup siemiatycki Jerzy (Pańkowski). Podjęto szereg ważnych decyzji, m.in. określono miejsce i datę spotkania: sobór zaplanowano w dniach 17-28 czerwca 2016 roku na wyspie Kreta. Poprawiono dokument: Misja Kościoła prawosławnego we współczesnym świecie. (Wkład Kościoła prawosławnego w realizację pokoju sprawiedliwości, wolności braterstwa i miłości między narodami i zniesienie dyskryminacji rasowej i innych) i w ten sposób został on zaakceptowany jako projekt przez Patriarchat Moskiewski i Gruziński. Poprawiono dokument poruszający zagadnienie przeszkód w zawarciu związku małżeńskiego. Ogólnie zmieniono jego temat i rozszerzono treść. W nowej formie dokument otrzymał brzmienie: Sakrament małżeństwa i przeszkody do jego zawarcia. Przyjęto również regulamin obrad soboru.

Podsumowując, należy stwierdzić, że przedstawiciele PAKP brali aktywny udział na wszystkich etapach przygotowań Soboru Wszechprawosławnego. Na tle ogólnoprawosławnym PAKP jest młodym Kościołem i stosunkowo niedużym, stąd też wniesiony przez ten Kościół wkład - w wymiarze proponowanych rozwiązań czy inicjatyw - nie był szczególny. Spośród przedstawicieli PAKP uczestniczących w procesie soborowych przygotowań z pewnością najwięcej $\mathrm{w}$ to dzieło wniósł arcybiskup Jeremiasz (Anchimiuk), początkowo jako członek delegacji PAKP, potem zaś jako jej przewodniczący. Dzięki trzydziestoletniej pracy w dziele przygotowań Soboru Wszechprawosławnego stał się on hierarchą z wielkim autorytetem i z uwagą słuchanym przez innych uczestników

${ }^{40}$ Zob. A. Kuźma, V Wszechprawosławna Konferencja Przedsoborowa, WPAKP 2015, nr 12 (313), s. 15. 
procesu przygotowawczego. Tym samym autorytet PAKP zyskał na znaczeniu wśród pozostałych autokefalicznych Kościołów lokalnych. Kontynuatorem tego dzieła stał się biskup siemiatycki Jerzy (Pańkowski). Doskonale władając językiem rosyjskim i greckim, pełni rolę swego rodzaju pomostu między prawosławiem greckim i rosyjskim i przyczynia się w ten sposób do wyjątkowości prawosławia polskiego.

\section{Bibliografia}

Anchimiuk J., Przygotowania do Soboru Wszechprawosławnego, WPAKP 1983, nr 1-2, s. 79-81.

Commision Interorthodoxe Préparatoire au Saint et Grand Concile, 21-27 fevrier 2011. Actes- Documents, Chambésy (maszynopis).

Decyzja Zwierzchników Cerkwi Prawosławnych, WPAKP 2014, nr 4 (293), s. 3.

Deuxième Conférence Panorthodoxe Préconciliaire. [Procès-verbaux et textes], Chambésy, 3-12 septembre 1982, [Synodica VIII], Chambésy (Genève) 1994 [=Synodica VIII].

Ionita V., Towards the Holy and Great Synod of the Orthodox Church. The Decisions of the Pan-Orthodox Meetings since 1923 until 2009, Fribourg 2014.

La IV Conférence Panorthodoxe Préconciliaire, Rapport de Son Éminence le métropolite Jérémie de Suisse, Secrétaire pour la Préparation du sain et grend Concile de l'Église orthodoxe, (maszynopis).

Kałużny T., Nowy sobór ogólnoprawosławny. Natura, historia przygotowań, tematyka, Kraków 2008 [=NSO].

Klinger J., Konferencja Przedstawicieli Kościołów Prawosławnych w Chambésy koło Genewy, „Cerkiewny Wiestnik” (1968) nr 8, s.12-14.

Kuźma A., Spotkanie Zwierzchników i Przedstawicieli Lokalnych Kościołów prawosławnych $w$ Konstantynopolu, WPAKP 2008, nr 12 (229), s. 4-5.

Kuźma A., IV Konferencja Przedsoborowa, WPAKP 2009, nr 7-8 (236-237), s. 4-5.

Kuźma A., V Wszechprawosławna Konferencja Przedsoborowa, WPAKP 2015, nr 12 (313), s. 15.

Межправославная Подготовительная Комиссия Святого и Великого Собора Православной Церкви, 10-17 ноября 1990 г., Шамбези-Женева 1991, maszynopis, 269 stron (w archiwum autora). 
Межправославная Подготовительная Комиссия Святого и Великого Собора Православной Церкви, 7-13 ноября 1993 г., Шамбези-Женева 1994, maszynopis, 225 stron (w archiwum autora).

Мнение епископов Польской Автокефальной Православной Церкви по вопросам: автокефалии, автономии, диаспрры и диптиха [1987], maszynopis, 2 strony (w archiwum autora).

Première Conférence Panorthodoxe Préconciliare. [Procès-verbaux et textes], Chambésy, 21-28 novembre 1976, [Synodica III], Chambésy (Genève) 1979 [=Synodica III].

Secrétariat pour la Préparation du Saint et Grande Concile de l'Eglise Orthodoxe, Доклад о совпадениях и расхождениях по четырем темам повестки дня IV Всеправославного Предсоборного Совещзания, Chambésy-Genève 1987, maszynopis, 16 stron (w archiwum autora).

Tofiluk J., O przygotowaniach do Soboru Wszechprawosławnego, „Elpis” 1 (1999) nr 1 (14), s. 69-84.

Troisième Conférence Panorthodoxe Préconciliaire, Chambésy, 28 Octobre 6 November 1986, [Synodica X], Chambésy-Genève 2014.

Всеправославное совещзание на о. Родосе, ŻMP 1961, nr 11, s. 3-4

Z prac Świętego Soboru Biskupów Polskiego Autokefalicznego Kościoła Prawosławnego, WPAKP 2014, nr 12 (301), s. 4-5.

\section{The Participation of the Polish Autocephalous Orthodox Church in the Preparations for the Pan-Orthodox Council}

\section{SUMMARY}

This article discusses the Polish Autocephalous Orthodox Church (PAOC) representatives' participation in the preparation process for the Pan-Orthodox Council from the First Pan-Orthodox Conference (1961) until the meeting of the leaders of local Orthodox Churches in January 2016. The members of the PAOC's delegation to meetings of parts of the Preparation Commission and all of the Pre-Council Conferences are listed. The main initiatives and positions of the PAOC's bishops regarding some of the elaborated topics are analyzed. The Church in Poland's position concerning topics that have not been included in the catalogue of prepared topics for the Pan-Orthodox Council are also presented. 
KEYWORDS: Pan-Orthodox Council, Polish Autocephalous Orthodox Church, Orthodox Church.

SŁOWA KLUCZOWE: Sobór Wszechprawosławny, Polski Autokefaliczny Kościół Prawosławny, Kościół prawosławny. 